\title{
Penta- and hexacoordinate silicon mixed dichelates with the $\mathrm{SiC}_{2} \mathrm{O}_{2} \mathrm{~N}(\mathrm{Cl})$ ligand environment
}

\author{
Inna Kalikhman, ${ }^{\mathrm{a} *}$ Boris Gostevskii, ${ }^{\mathrm{b}}$ Vadim Pestunovich, ${ }^{\mathrm{b} \dagger}$ Nikolaus Kocher, \\ Dietmar Stalke, ${ }^{\mathrm{c}}$ and Daniel Kost ${ }^{\mathrm{a}}{ }^{*}$ \\ ${ }^{a}$ Department of Chemistry, Ben-Gurion University of the Negev, Beer-Sheva 84105, Israel \\ ${ }^{b}$ Favorsky Irkutsk Institute of Chemistry, Russian Academy of Sciences, Irkutsk, Russia, ${ }^{c}$ Institut \\ für Anorganische Chemie, Universität Würzburg, am Hubland D-97074 Würzburg, Germany \\ E-mail: kostd@bgu.ac.il
}

Dedicated to Professor Edmunds Lukevics on the occasion of his $70^{\text {th }}$ birthday

\begin{abstract}
New dichelate complexes of silicon with different chelate rings have been prepared by transsilylation, using $\mathrm{ClCH}_{2} \mathrm{SiMeCl}_{2}$ and various $\mathrm{N}$ - and O-TMS-hydrazides and amides. Their structures and possible transformations between penta and hexacoordinate complexes have been studied. Many of the complexes are pentacoordinate ionic chloride salts, with charges on an ammonium nitrogen or on silicon. Compounds 5a,b have a zwitterionic aminimide structure, with a possible additional positive charge on silicon. 12 Is the only compound in the series in which penta- hexacoordinate complex exchange is found, involving reversible non-ionic N-Si bond dissociation. 16 is the first reported mixed dichelate siliconium-ion salt with two $\mathrm{O} \rightarrow \mathrm{Si}$ dative bonds. Its structure, as well as that of $\mathbf{5 a}$, is established by crystallographic analysis.
\end{abstract}

Keywords: Pentacoordinate, hexacoordinate, silicon, siliconium, amide-hydrazide dichelate, zwitterion

\section{Introduction}

There has been considerable interest in recent years in the chemistry of hypercoordinate silicon compounds. ${ }^{1}$ Numerous hydrazide-based silicon bischelates, sharing the $\mathrm{SiCN}_{2} \mathrm{O}_{2} \mathrm{Hal}$ (or $\mathrm{SiN}_{2} \mathrm{O}_{2} \mathrm{Hal}_{2}$ ) ligand environments have been prepared by transsilylation, ${ }^{2}$ and their reactivities ${ }^{3}$ and dynamic properties ${ }^{4}$ have been investigated. This particular family of silicon compounds showed remarkable chemical flexibility: (1) equilibrium ionic dissociation, which is highly sensitive to changes in solvent, temperature, ligands, steric bulk and counterion; ${ }^{5}$ (2) non-ionic dissociation of the $\mathrm{N} \rightarrow \mathrm{Si}$ dative bond. ${ }^{6}$ (3) A special case of reversible ionization of a 
hexacoordinate silicon complex has been described as a novel "tautomeric equilibrium". ${ }^{7}$ It differs from the formation of siliconium-ion salts in that a formal positive charge resides on nitrogen, in a dimethylammonium cation. A single case of this type of equilibrium was reported. ${ }^{7}$

The present work describes the extension of this family of silicon compounds to mixed dichelates with the $\mathrm{SiC}_{2} \mathrm{O}_{2} \mathrm{~N}(\mathrm{Cl})$ ligand framework, and the study of their structure and stereodynamic properties.

Synthesis of silicon chelates by transsilylation using polyhalosilanes and TMS-hydrazides offers a convenient route to $\mathrm{N} \rightarrow \mathrm{Si}$ coordinated silicon compounds (Eq 1). ${ }^{2}$ When a chloromethyl-substituted polyhalosilane is used $\left(\mathrm{ClCH}_{2} \mathrm{SiMe}_{2} \mathrm{Cl}^{8}{ }^{8} \quad \mathrm{ClCH}_{2} \mathrm{SiMeCl}_{2},{ }^{7}\right.$ $\mathrm{ClCH}_{2} \mathrm{SiCl}_{3}{ }^{9}$ ), the initial transsilylation is followed by an internal alkylation, forming an $\mathrm{O} \rightarrow \mathrm{Si}$ coordinated compound (Eq 2, 3). ${ }^{9,10}$ In the case of $\mathrm{R}=\mathrm{CF}_{3}$ the transsilylation takes place in two distinct steps (Eq 4), and the intermediate dichloromonochelate (3) has been isolated. ${ }^{7}$

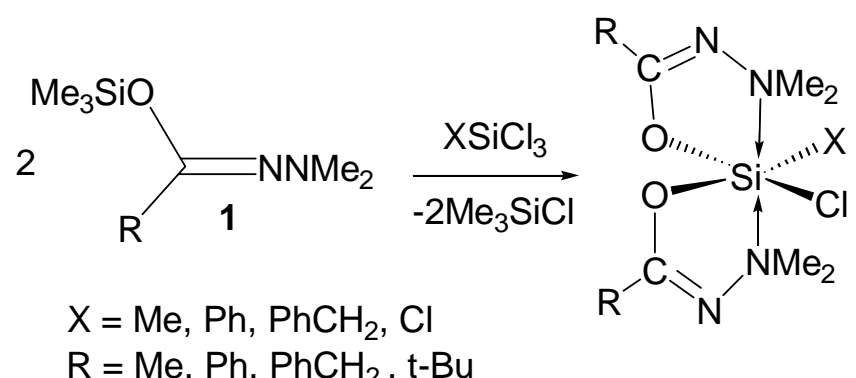

$\mathrm{R}=\mathrm{Me}, \mathrm{Ph}, \mathrm{PhCH}_{2}, \mathrm{t}-\mathrm{Bu}$<smiles>[R]C1=NN(C)C[Si](C)(Cl)O1</smiles>

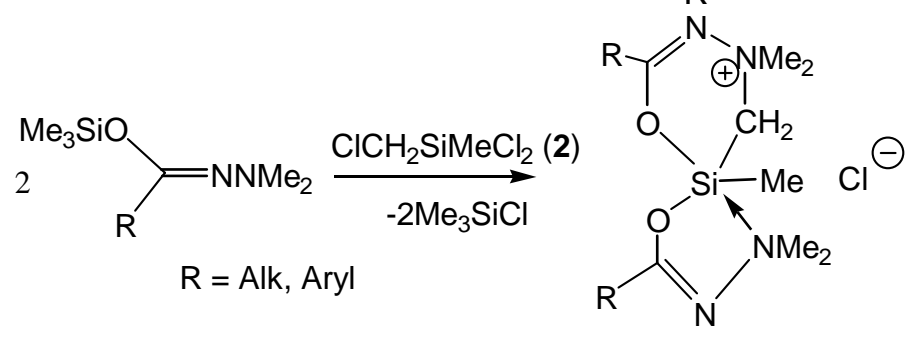

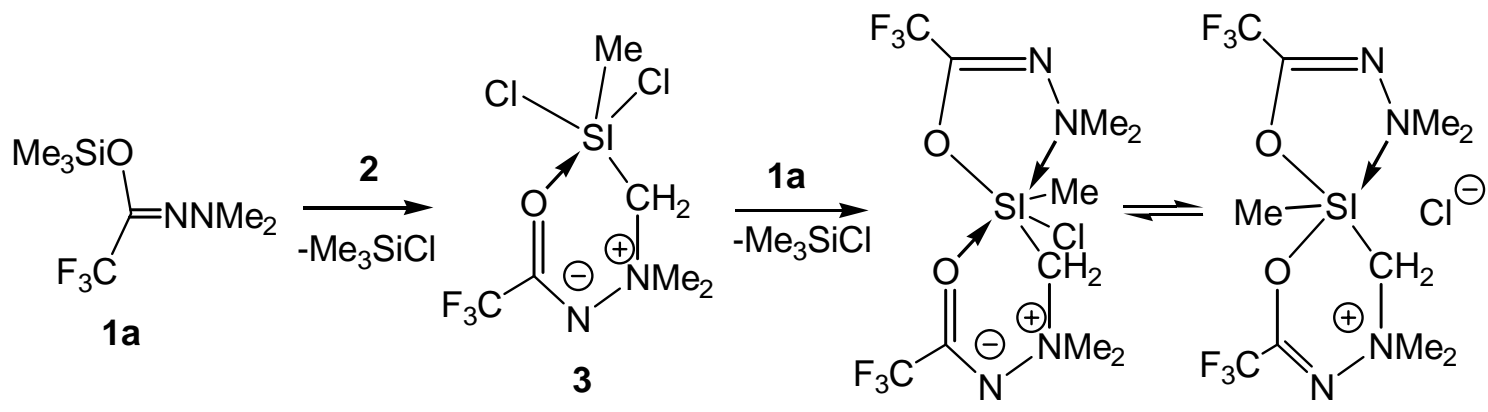




\section{Results and Discussion}

The monochelate intermediate $\mathbf{3}$ is the starting point for a number of new silicon dichelates. It belongs to the family of aminimides, ${ }^{11}$ i.e., it constitutes an ylide with adjacent oppositely charged nitrogen atoms. The particular stability of $\mathbf{3}$ with the $\mathrm{CF}_{3}$ group ${ }^{7}$ was utilized to prepare a series of mixed dichelates, by transsilylation with three different trimethylsilyl (TMS) hydrazides. These are the first reported stepwise syntheses of mixed dichelates, by application of two consecutive transsilylation processes. The three reagent types used for the second transsilylation step are: 1) $\mathrm{RCON}(\mathrm{Me}) \mathrm{N}(\mathrm{Me}) \mathrm{SiMe}_{3}(\mathbf{4 a , b})$ 2) $\mathrm{RC}\left(\mathrm{OSiMe}_{3}\right)=\mathrm{NN}=\mathrm{CMe}_{2}(\mathbf{6 a}, \mathbf{b})$ and 3) $\mathrm{RC}\left(\mathrm{OSiMe}_{3}\right)=\mathrm{NNMe}_{2}$ (1).

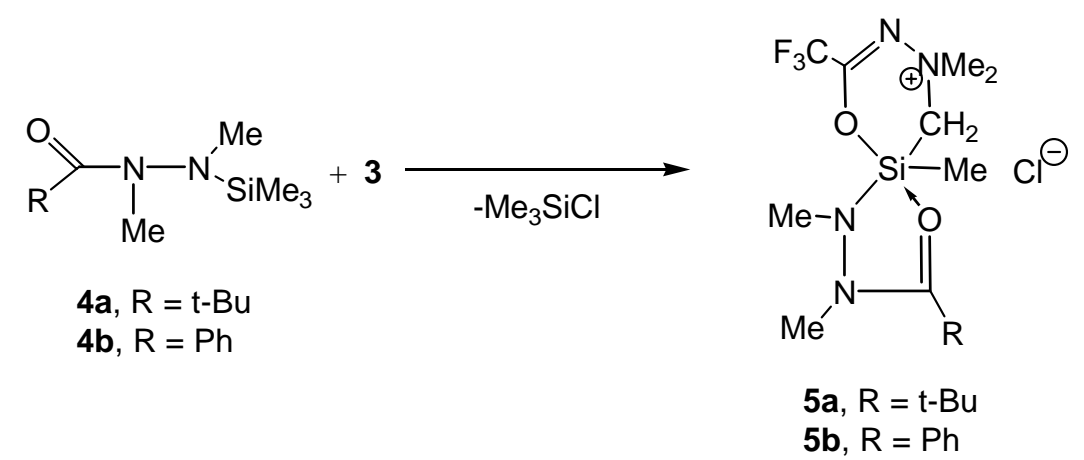

The products 5 obtained from $N, N^{\prime}$-dimethyl( $N$-TMS)hydrazides (4a,b) are shown in Eq 5. A crystal structure was obtained for $\mathbf{5 a}$, a new pentacoordinate silicon dichelate, and is depicted in Fig 1. 5a is ionic in the crystal ( $\mathrm{Si}-\mathrm{Cl}$ distance: $5.23 \AA$ ), and the temperature independent ${ }^{29} \mathrm{Si}$ NMR spectra with chemical shifts typically pentacoordinate $\left({ }^{29} \mathrm{Si}: \mathbf{5 a}-75.3 ; \mathbf{5 b}-75.5 \mathrm{ppm}\right)$ indicate that this is also the only observable structure in $\mathrm{CDCl}_{3}$ solution. Whether the charge in 5a and similar ionic complexes resides only on the ammonium nitrogen, or on nitrogen and on silicon (with an additional negative charge on the nitrogen adjacent to the ammonium nitrogen), is not entirely clear (see discussion below). The structure of 5a is a slightly distorted trigonal bipyramid (TBP), with the electronegative oxygen ligands occupying the axial positions. The two Si-O bonds are remarkably short for axial ligands, ${ }^{1 b, c}$ and the relatively small difference between them makes the distinction of dative and covalent bonds impractical (Table 1). 


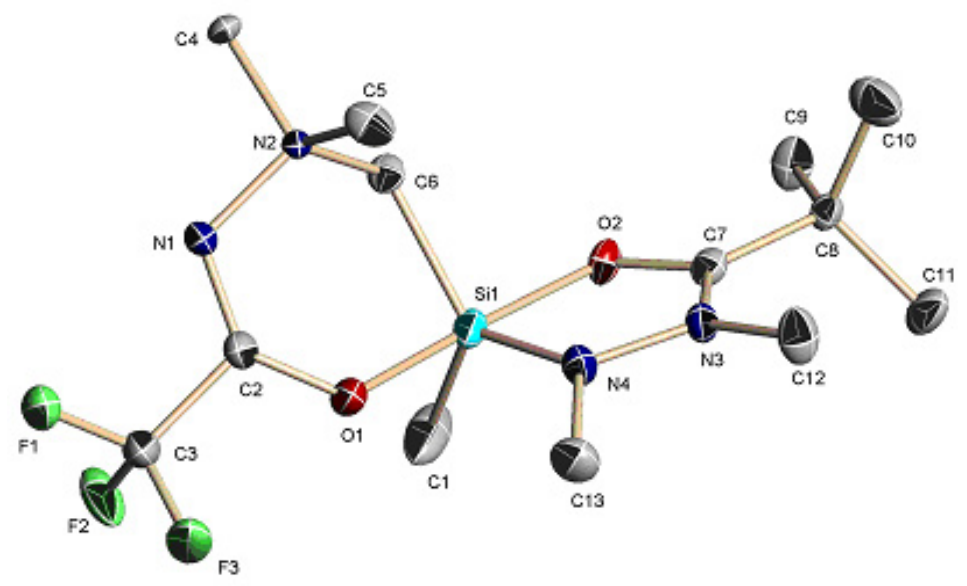

Figure 1. Molecular structure in the crystal of 5a. Anisotropic displacement parameters are depicted at the $50 \%$ probability level. Hydrogen atoms and chloride are omitted for clarity.

Table 1. Selected bond lengths $(\AA)$ and angles (deg) in the crystals of 5a and $\mathbf{1 6}$

\begin{tabular}{lll}
\hline Bond & $\mathbf{5 a}$ & $\mathbf{1 6}$ \\
\hline Si-N & $1.753(1)$ & $1.762(1)$ \\
Si-O (amide) & $1.8173(9)$ & $1.8518(9)$ \\
Si-O (hydrazide) & $1.828(1)$ & $1.8198(9)$ \\
Si-C (Me) & $1.859(2)$ & $1.854(1)$ \\
Si-C (CH $)$ & $1.897(1)$ & $1.884(1)$ \\
C-O (hydrazide) & $1.281(2)$ & $1.290(2)$ \\
C-N (hydrazide) & $1.2749(2)$ & $1.305(2)$ \\
C-O (amide) & $1.293(2)$ & $1.285(2)$ \\
C-N (amide) & $1.303(2)$ & $1.306(2)$ \\
\hline Angle & & $170.88(5)$ \\
\hline O-Si-O & $172.17(5)$ & $119.51(6)$ \\
C-Si-C & $113.99(7)$ & $118.72(6)$ \\
N-Si-C (Me) & $124.00(7)$ & $121.77(6)$ \\
N-Si-C (CH $)$ & $122.00(5)$ & $360.00(18)$ \\
$\Sigma($ equatorial angles) & $359.90(19)$ & \\
\hline
\end{tabular}

Thus, there is no detectable tautomeric equilibrium in $\mathbf{5 a}$ and $\mathbf{5 b}$, and the compounds are essentially pentacoordinate charged silicon-complex chloride salts.

Using the second set of TMS-hydrazides, $\mathbf{6 a}, \mathbf{b}$, gave a similar result (Eq 6): transsilylation afforded only, within detection level, mixed pentacoordinate dichelates $(\mathbf{7 a}, \mathbf{b})$ bearing a positive charge. The ${ }^{29} \mathrm{Si}$ chemical shifts for $\mathbf{7 a}, \mathbf{b}$ (-73.6, -74.9 ppm, respectively in $\mathrm{CDCl}_{3}$ solution) are characteristic of pentacoordination, and do not change significantly upon changing the temperature. Thus no equilibrium with a possible hexacoordinate complex can be found. 


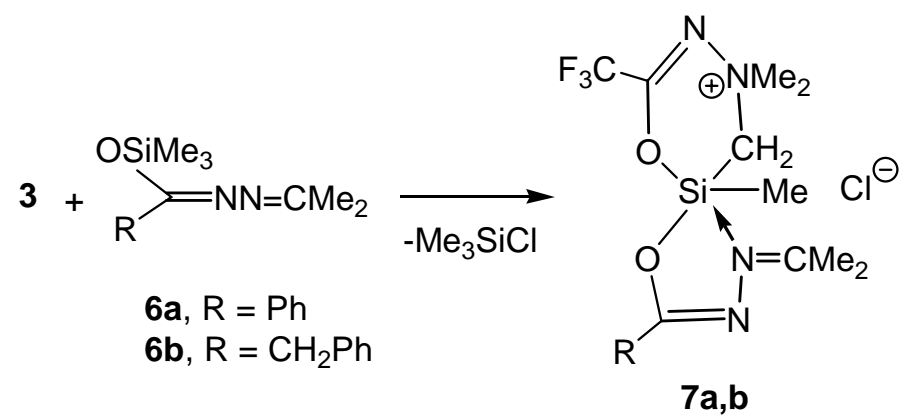

The third series of compounds were synthesized from $\mathbf{3}$ and $\mathrm{O}$-(TMS) $N, N$ dimethylhydrazides (1), to form dichelates $\mathbf{8 b}, \mathbf{c}$ (Eq 7). The latter differ from the products of Eq 3,4 , in that the remote substituents $\mathrm{R}$ at the chelate rings are different. In this case, like in the two previous examples, no tautomeric equilibrium could be detected and the compounds constitute formal silicon-complex chloride salts.

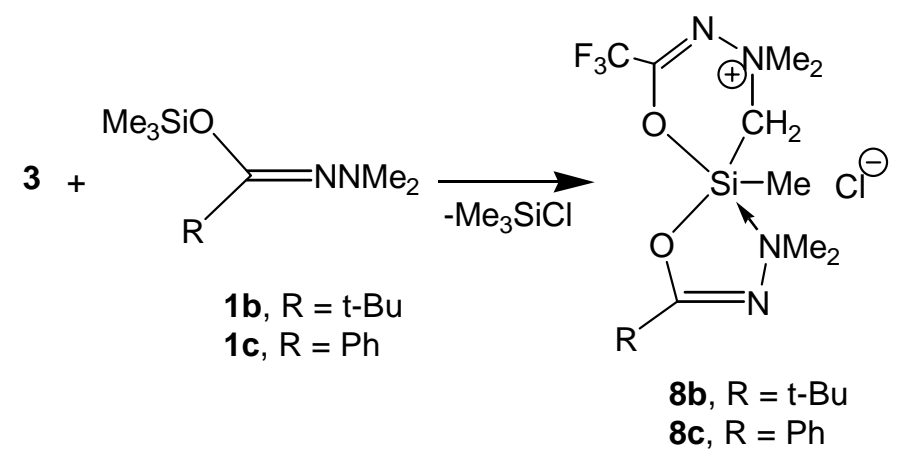

The ${ }^{1} \mathrm{H}$ NMR spectra of $\mathbf{8 b}, \mathbf{c}$ in $\mathrm{CDCl}_{3}$ solutions feature diastereotopic methylene protons as well as methyl groups in each of the $\mathrm{Me}_{2} \mathrm{~N}$ groups, as a result of the silicon chiral center. However, the signals due to the pairs of diastereotopic groups broaden upon increase of the sample's temperature, suggesting that a dynamic process is taking place. In $\mathbf{8 c}$ these changes could be monitored in $\mathrm{CDCl}_{3}$ solution for the least separated signal pair, in the one of $\mathrm{NNMe}_{2}$ groups. These two singlets ( 3.64 and $3.67 \mathrm{ppm}, \Delta v=15.3 \mathrm{~Hz}$ ) coalesce at $\mathrm{T}_{\mathrm{c}}=326 \mathrm{~K}$, corresponding to an exchange barrier $\Delta \mathrm{G}^{*}=16.9 \pm 0.3 \mathrm{kcal} \mathrm{mol}^{-1}$. The other signal pairs were considerably more separated at low temperature, and hence their coalescence temperatures are expected at higher temperatures, which could not be reached in $\mathrm{CDCl}_{3}$ solution.

Similar exchange line-broadening was observed in the ${ }^{1} \mathrm{H}$ NMR spectra of $\mathbf{8 b}$, and the barrier was determined from the coalescence of the $\mathrm{NNMe}_{2}$ singlets $\left(\mathrm{T}_{\mathrm{c}}=343 \mathrm{~K}, \Delta \mathrm{G}^{*}=17.2 \pm\right.$ $0.3 \mathrm{kcal} \mathrm{mol}^{-1}$ ). In both compounds the fact that signals due to diastereotopic pairs coalesce simultaneously (i.e., in the same exchange process) on both of the chelate rings indicates that exchange is due to rapid inversion of configuration at the chiral silicon center. Inversion at silicon could result from either an intramolecular nondissociative exchange, such as the Berry pseudorotation, ${ }^{12}$ or from dissociation of the $\mathrm{N} \rightarrow$ Si dative bond followed by reclosure of the ring 
by attack of the ligand from the opposite direction. ${ }^{13}$ The available NMR data do not allow a distinction between these two mechanisms.

Mixed amide-hydrazide dichelates. Since all of the approaches described above failed to produce another example of tautomeric equilibrium of the kind reported previously, ${ }^{7}$ the reactions shown in Eq 8-9 were carried out, in which one chelate ring is derived from an amide and the other from a hydrazide functionality. In the first step the neutral pentacoordinate intermediate 11a was synthesized from $N$-TMS- $N$-(methyl)trifluoroacetamide (10a, Eq 8) and (chloromethyl)methyldichlorosilane (2), in analogy to the reaction with (chloromethyl)dimethylchlorosilane reported by Yoder. ${ }^{8 a, b}$ Pentacoordination of the silicon atom in 11a is evident from the temperature dependence of its ${ }^{29}$ Si NMR (see Experimental).

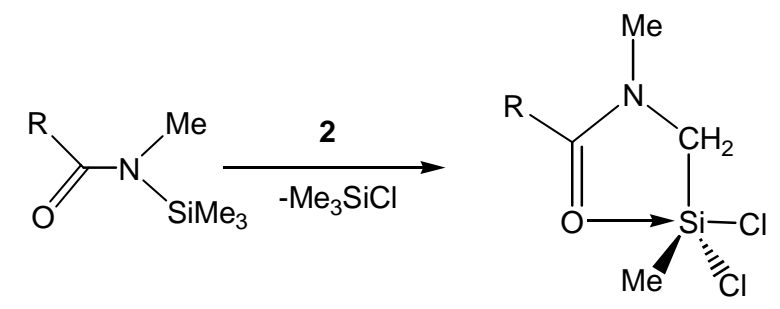

10a, $\mathrm{R}=\mathrm{CF}_{3}$ 10b, $\mathrm{R}=\mathrm{Me}$ 11a, $\mathrm{R}=\mathrm{CF}_{3}$ 11b, $\mathrm{R}=\mathrm{Me}$

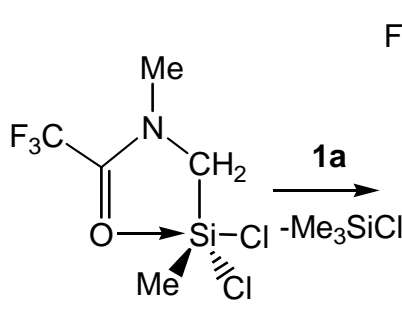

$11 \mathrm{a}$<smiles>C=C[Si]1(Cl)(Cl)(OC(=NC)C(F)(F)F)OC(C(F)(F)F)=NN1C</smiles>

12

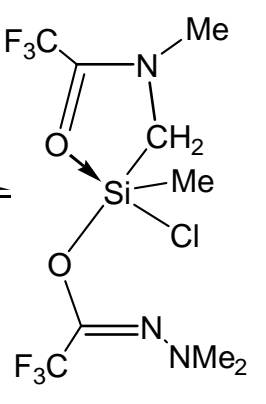

13

In the second step (Eq 9) the mixed amide-hydrazide complex 12 was prepared by further transsilylation from the dichloro intermediate 11a. The ${ }^{29} \mathrm{Si}$ NMR spectra of $\mathbf{1 2}$ in toluene- $\mathrm{d}_{8}$ solution feature substantial temperature dependence of the ${ }^{29} \mathrm{Si}$ chemical shift (Fig 2), in agreement with an equilibrium interconversion between penta immediately and hexacoordinate complexes. However, in contrast to the temperature dependence observed in the ionic, solvent driven dissociation of hexacoordinate complexes (cf. Eq 3), favoring pentacoordination at low temperatures, ${ }^{5}$ the temperature dependence in $\mathbf{1 2}$ suggests a non-ionic dissociation: the dissociated pentacoordinate species is favored as the temperature is increased (Fig. 2). 


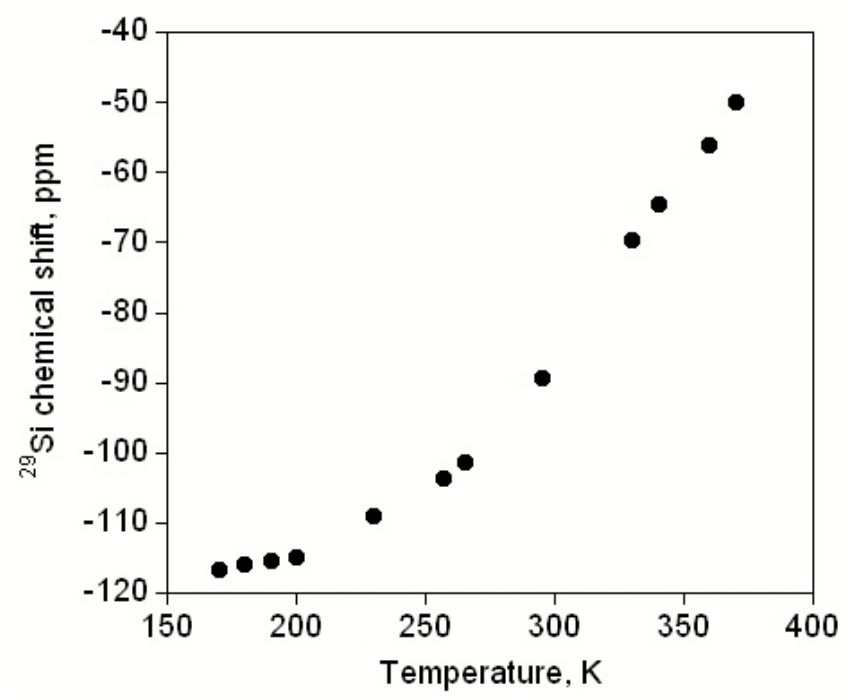

Figure 2. Temperature dependence of the ${ }^{29} \mathrm{Si}$ NMR spectrum of $\mathbf{1 2}$ in toluene- $\mathrm{d}_{8}$ solution

Two different types of bond dissociation could lead to the observed temperature dependence of the ${ }^{29} \mathrm{Si}$ chemical shift of $\mathbf{1 2}$, namely $\mathrm{N} \rightarrow \mathrm{Si}$ or $\mathrm{O} \rightarrow \mathrm{Si}$ cleavage. To determine which one of these bonds dissociates, we examine the temperature dependence of the ${ }^{13} \mathrm{C} N M R$ spectra of 12 in toluene- $\mathrm{d}_{8}$ solution. The ${ }^{13} \mathrm{C}=\mathrm{N}$ resonance of the hydrazide fragment shifts to higher field, from 155.8 to $146.2 \mathrm{ppm}$, upon increasing the temperature from $200 \mathrm{~K}$ to $360 \mathrm{~K}$, while the ${ }^{13} \mathrm{C}=\mathrm{N}$ resonance of the amide fragment $(158.0 \mathrm{ppm})$ remains essentially temperature independent. The ${ }^{13} \mathrm{C}$ chemical shift of the hydrazide fragment at $360 \mathrm{~K}$ is near that of the noncoordinated precursor TMS-hydrazide $1 \mathbf{a}\left(\delta{ }^{13} \mathrm{C}=\mathrm{N} 140.0 \mathrm{ppm}\right) .{ }^{6}$ These two facts (temperature dependence and similarity of the ${ }^{13} \mathrm{C}$ resonance to that of the noncoordinated analog) strongly suggest that the observed dissociation process $(\mathbf{1 2} \leftrightarrow \mathbf{1 3})$ corresponds to $\mathrm{N} \rightarrow \mathrm{Si}$ cleavage in the hydrazide chelate ring. Support for the proposed nonionic dissociation comes also from the solubility of $\mathbf{1 2}$ in toluene- $\mathrm{d}_{8}$ solution, since the ionic silicon complexes generally dissolve in $\mathrm{CDCl}_{3}$, but not in toluene- $\mathrm{d}_{8}$ to any significant extent. ${ }^{5,7}$ This nonionic dissociation of mixed dichelates is a new example for the dynamic equilibrium between hexa immediately and pentacoordinate silicon chelates.

Mixed amide-hydrazide dichelate with two $\mathbf{O} \rightarrow$ Si dative bonds. Another amide hydrazide mixed complex (15) with two $\mathrm{O} \rightarrow \mathrm{Si}$ coordination bonds, was obtained by two consecutive transsilylation steps, as shown in Eq 8 (11b) and Eq 10. 15 is a pentacoordinate siliconium ion chloride, as evident from its ${ }^{29} \mathrm{Si}$ chemical shift, which is only slightly temperature dependent ( $\delta$-58.8 ppm at $330 \mathrm{~K},-59.6 \mathrm{ppm}$ at $300 \mathrm{~K}$, and $-59.9 \mathrm{ppm}$ at $260 \mathrm{~K}$ ). Substitution of the chloride counterion in 15 by tetraphenylborate (16) enabled isolation of a single crystal which was subjected to X-ray diffraction analysis. The resulting molecular structure in the crystal is depicted in Fig. 3, and selected bond lengths and angles are listed in Table 1. 


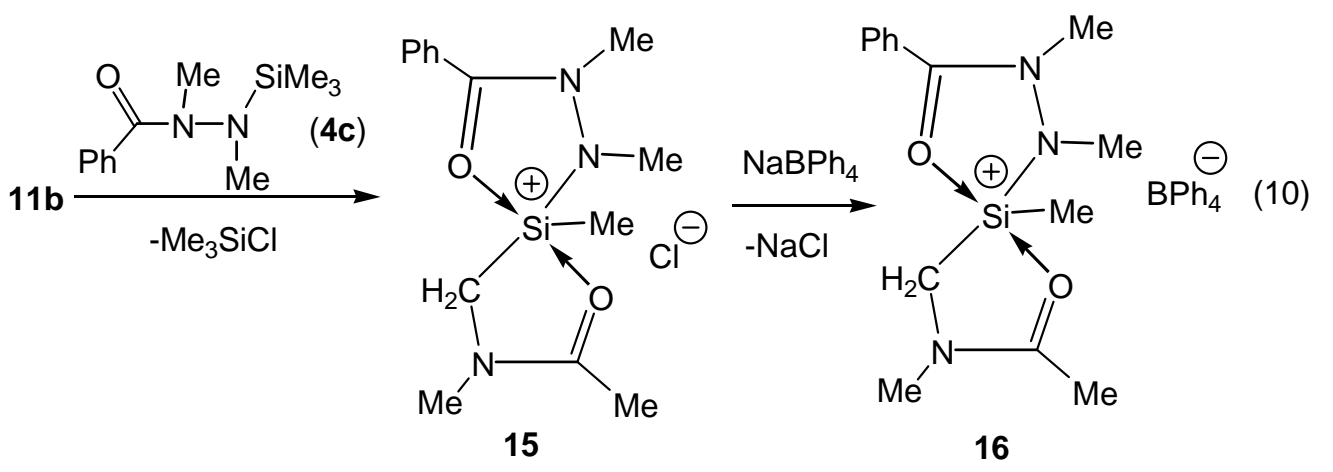

The crystal data in Table 1 and Fig 3 clearly confirm the ionic nature of 16: the Si-B distance is greater than $7 \AA$, well beyond any reasonable covalent bond.

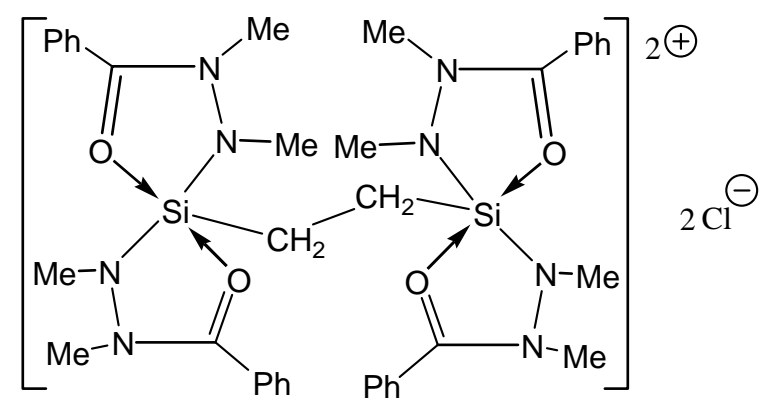

17

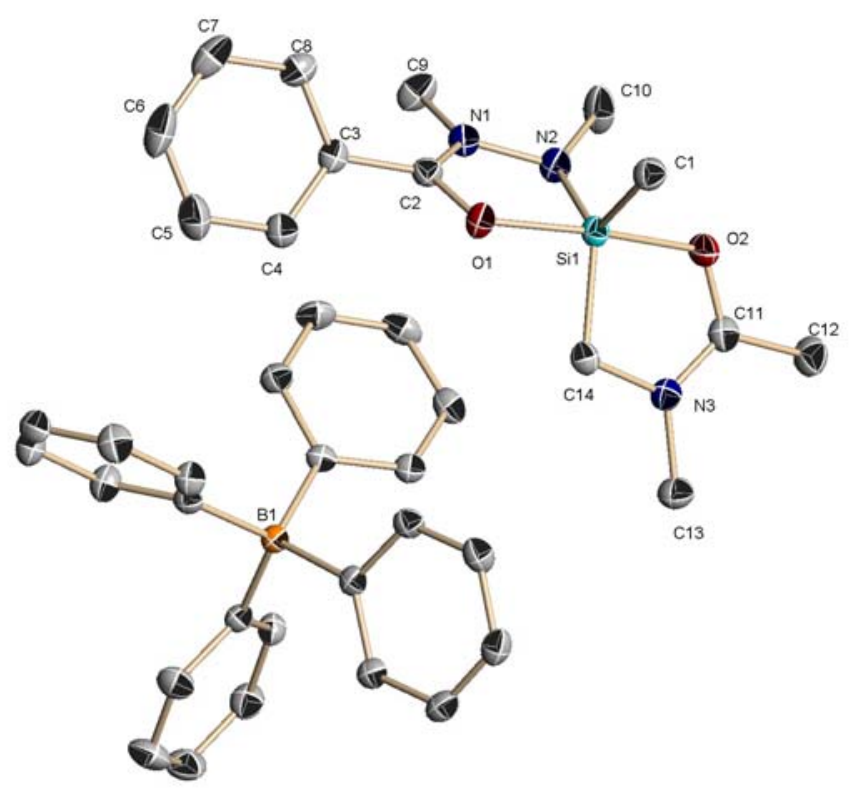

Figure 3. Molecular structure in the crystal of 16. Anisotropic displacement parameters are depicted at the $50 \%$ probability level, and hydrogen atoms are omitted for clarity. 
The geometry about the silicon atom in $\mathbf{1 6}$ (Table 1) is a distorted TBP, with oxygen atoms occupying the axial positions, and forming an $\mathrm{O}-\mathrm{Si}-\mathrm{O}$ angle of $170.88^{\circ}$. The dative $\mathrm{O} \rightarrow \mathrm{Si}$ bonds are generally comparable to those in other pentacoordinate complexes; ${ }^{14}$ thus, the hydrazide-side Si-O distance is slightly longer than in the dication dihydrazide complex 17 (1.802 and 1.807 $\AA),{ }^{15}$ and the amide-side Si-O bond is similar to those reported previously for amide-chelate compounds. $^{14}$

Examination of the geometrical data in Table 1 reveals a remarkable resemblance in the bond lengths and some of the bond angles of 5a and 16. 16 clearly has a formal positive charge at silicon, which is partly distributed to the adjacent amide-type donor atoms. The location of charges in $\mathbf{5 a}$ (and by analogy in $\mathbf{5 b}$ ) is not as obvious: $\mathbf{5}$ may be an ion pair with positive charge residing on the ammonium nitrogen atom, or it may have two positive charges, one on nitrogen and one on silicon (with similar charge distribution by the donor ligands) and two corresponding negative charges, on chloride and the amide nitrogen. The close similarity of general geometry and bond lengths in the two crystals (5a and 16), suggests that both have similar positive charge distributions around silicon, and that the $\mathrm{N}-\mathrm{NMe}_{2}$ moiety in 5a constitutes a separate and independent zwitterionic "aminimide" fragment, ${ }^{11}$ which has little effect on charges in other parts of the molecule. This implies that 5a should be better represented by the formula $\mathbf{5} \mathbf{a}^{\mathbf{2}}$, and is hence considered a donor-stabilized silyl cation.

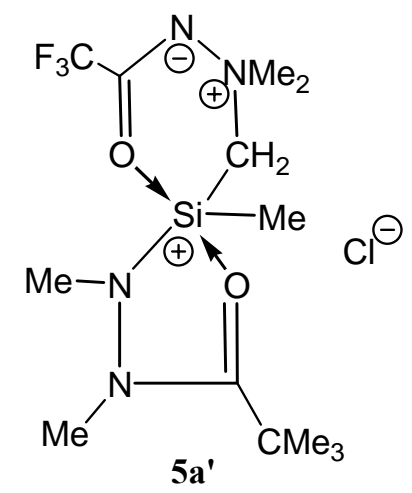

\section{Experimental Section}

General Procedures. The reactions were carried out under dry argon using Schlenk techniques. Solvents were dried and purified by standard methods. NMR spectra were recorded on a Bruker Avance DMX-500 spectrometer operating at 500.13, 125.76, and 99.36 MHz, respectively, for ${ }^{1} \mathrm{H},{ }^{13} \mathrm{C}$ and ${ }^{29} \mathrm{Si}$ spectra. Spectra are reported in $\delta$ (ppm) relative to TMS, as determined from standard residual solvent-proton (or carbon) signals for ${ }^{1} \mathrm{H}$ and ${ }^{13} \mathrm{C}$ and directly from TMS for ${ }^{29} \mathrm{Si}$. Melting points were measured in sealed capillaries using a Büchi melting point instrument, and are uncorrected. Elemental analyses were performed by Mikroanalytisches Laboratorium Beller, Göttingen, Germany. 
Single crystal X-ray diffraction measurements were performed on a Nonius Kappa-CCD Diffractometer. Experimental details are listed in Table 2, and full data tables are included in the Supporting Information. Crystallographic data for 5a and $\mathbf{1 6}$ have been deposited with the Cambridge Crystallographic Data Centre. The CCDC numbers are listed in Table 2. Copies of the data can be obtained free of charge on application to CCDC, 12 Union Road, Cambridge CB2 1EZ, UK [fax: (internat.) +44(1223)336-033; e-mail: deposit@ccdc.cam.ac.uk].

Table 2: Crystal data and experimental parameters for the structure analyses of $\mathbf{5 a}$ and $\mathbf{1 6}$

\begin{tabular}{|c|c|c|}
\hline & $5 \mathbf{a}$ & 16 \\
\hline CCDC number & 292099 & 292100 \\
\hline Empirical formula & $\mathrm{C}_{13} \mathrm{H}_{26} \mathrm{ClF}_{3} \mathrm{~N}_{4} \mathrm{O}_{2} \mathrm{Si}$ & $\mathrm{C}_{38} \mathrm{H}_{42} \mathrm{BN}_{3} \mathrm{O}_{2} \mathrm{Si}$ \\
\hline Form mass, $\mathrm{g} \mathrm{mol}^{-1}$ & 390.92 & 611.65 \\
\hline Collection T, K & 293(2) & $100(2)$ \\
\hline Cryst. syst. & monoclinic & monoclinic \\
\hline Space group & $\mathrm{P} 2(1) / \mathrm{c}$ & $\mathrm{P} 2(1) / \mathrm{c}$ \\
\hline$a, \AA$ & $13.0743(10)$ & $9.9800(6)$ \\
\hline$b, \AA$ & $15.8341(12)$ & $17.4132(11)$ \\
\hline$c, \AA$ & $9.5980(7)$ & $18.9080(12)$ \\
\hline$\alpha, \operatorname{deg}$ & 90 & 90 \\
\hline$\beta$, deg & 108.1570(10) & $93.1380(10)$ \\
\hline$\gamma$, deg & 90 & 90 \\
\hline$V, \AA^{3}$ & 1888.0(9) & $3281.0(4)$ \\
\hline$Z$ & 4 & 4 \\
\hline$\rho_{\text {calc }}, \mathrm{Mg} / \mathrm{m}^{3}$ & 1.375 & 1.238 \\
\hline$F(000)$ & 824 & 1304 \\
\hline$\theta$ range, deg & $1.64-27.10$ & $1.59-28.30$ \\
\hline no. of coll. reflns & 15811 & 28038 \\
\hline no. of indep. reflns & 4128 & 7643 \\
\hline$R$ int & 0.0187 & 0.0276 \\
\hline no. of reflns used & 4128 & 7643 \\
\hline no. params. & 321 & 422 \\
\hline Goof & 1.062 & 1.031 \\
\hline$R 1^{a}{ }_{\mathrm{wR}} 2^{\mathrm{b}}[I>2 \sigma(I)]$ & $0.0305 \quad 0.0819$ & $0.0424 \quad 0.1127$ \\
\hline$R 1^{a} \mathrm{wR}^{\mathrm{b}}$ (all data) & 0.03330 .0838 & 0.04810 .1178 \\
\hline $\begin{array}{l}\text { max/min.res electron } \\
\text { dens }\left(\mathrm{e}^{-3}\right)\end{array}$ & $0.395 /-0.295$ & $0.538 /-0.229$ \\
\hline
\end{tabular}




\section{[ $N$-(Dimethyl) $N$-(trifluoroacethydrazido)methyl-C,O][N, $N^{\prime}($ dimethyl)pivalohydrazido-}

$\mathbf{N}, \mathbf{O}$ ]methylsilicon chloride (5a). To a solution of $0.518 \mathrm{~g}$ (3.59 mmol) of $\mathrm{ClCH}_{2} \mathrm{SiMeCl}_{2}$ (2) in $5 \mathrm{~mL}$ of chloroform was added $0.724 \mathrm{~g}(3.17 \mathrm{mmol})$ of $1 \mathrm{a}$ in one portion. The mixture was kept $1 \mathrm{~h}$ at room temperature, followed by removal of volatiles under reduced pressure (1 mmHg). The remaining oil was treated with $20 \mathrm{~mL}$ of hexane, and warmed up to reflux temperature for 1 h, after which a powder had precipitated. The solvent was decanted off, and the washing repeated once. The solid residue (crude $\mathbf{3}^{7}$ ) was dried at $0.01 \mathrm{mmHg}$ for $1 \mathrm{~h}$ and used without further purification. To the crude 3 was added $10 \mathrm{~mL}$ of $\mathrm{CHCl}_{3}$ and 0.721 (3.33 mmol) 4a. The mixture was heated to boiling for $5 \mathrm{~min}$, and was allowed to cool to RT for $1 \mathrm{~h}$, followed by low pressure evaporation of the solvent. The residue was washed twice, each with $20 \mathrm{~mL}$ of warm hexane, and then dried in vacuum. $0.88 \mathrm{~g}$ of $\mathbf{5 a}$ (71\% yield) was obtained, mp 149-150 ${ }^{\circ} \mathrm{C}$. Crystals suitable for crystallographic analysis were obtained by recrystallization from THF and chloroform. ${ }^{1} \mathrm{H}$ NMR (CDCl $3,300 \mathrm{~K}): \delta 0.29$ (s, 3H, MeSi), 1.28 (s, 9H, t-Bu), 2.87, 3.44, 3.49, 3.74 (4s, 12H, $\mathrm{NMe}), 3.27,3.75\left(\mathrm{ABq},{ }^{2} J=15.8 \mathrm{~Hz}, 2 \mathrm{H}, \mathrm{CH}_{2}\right) .{ }^{13} \mathrm{C} \mathrm{NMR}\left(\mathrm{CDCl}_{3}, 300 \mathrm{~K}\right): \delta 2.0(\mathrm{MeSi}), 27.6$ $\left(\mathrm{C}\left(\mathrm{CH}_{3}\right)_{3}\right), 36.0\left(\mathrm{C}\left(\mathrm{CH}_{3}\right)_{3}\right), 32.4,35.5,56.2,58.9(\mathrm{NMe}), 57.6\left(\mathrm{CH}_{2}\right), 116.4\left(\mathrm{q},{ }^{1} J_{\mathrm{CF}}=282 \mathrm{~Hz}\right.$, $\left.\mathrm{CF}_{3}\right), 156.3\left(\mathrm{q},{ }^{2} J_{\mathrm{CF}}=3.7 \mathrm{~Hz}, C \mathrm{CF}_{3}\right), 173.8(\mathrm{t}-\mathrm{BuC}=\mathrm{O}) .{ }^{29} \mathrm{Si}\left(\mathrm{CDCl}_{3}, 300 \mathrm{~K}\right): \delta-75.3$. Anal. Calcd for $\mathrm{C}_{13} \mathrm{H}_{26} \mathrm{ClF}_{3} \mathrm{~N}_{4} \mathrm{O}_{2} \mathrm{Si}$ : C, 39.94; H, 6.70; N, 14.33. Found: C, 39.56; H, 6.89; N, 14.24 .

[ $N$-(dimethyl)N-(trifluoroacethydrazido)methyl-C,O][N, $N^{\prime}($ dimethyl)benzhydrazido-

$\mathbf{N , O}$ ]methylsilicon chloride (5b). 5b was prepared as described for 5a, using $0.593 \mathrm{~g}$ (3.63 mmol) of 2 in $10 \mathrm{~mL} \mathrm{CHCl}_{3}$ and $0.717 \mathrm{~g}(3.14 \mathrm{mmol})$ of $\mathbf{1 a}$, followed by reaction with $0.771 \mathrm{~g}$ (3.26 mmol) $\mathbf{4 b}$. $0.547 \mathrm{~g}$ of $\mathbf{5 b}$ (91\% yield) was obtained, mp 127-128 ${ }^{\circ} \mathrm{C} .{ }^{1} \mathrm{H} \mathrm{NMR}\left(\mathrm{CDCl}_{3}, 300\right.$ $\mathrm{K}): \delta 0.36$ (s, 3H, MeSi), 3.03, 3.40, 3.47, 3.62 (4s, 12H, NMe), 3.32, $4.21\left(\mathrm{ABq},{ }^{2} J=16.0 \mathrm{~Hz}\right.$, $\left.2 \mathrm{H}, \mathrm{CH}_{2}\right), 7.24-7.68$ (m, 5H, Ph). ${ }^{13} \mathrm{C} \mathrm{NMR}\left(\mathrm{CDCl}_{3}, 300 \mathrm{~K}\right): \delta 2.81(\mathrm{MeSi}), 32.6,37.1,56.6$, $59.1(\mathrm{NMe}), 57.7\left(\mathrm{CH}_{2}\right), 125.4,128.7,129.7,132.8(\mathrm{Ph}), 116.4\left(\mathrm{q},{ }^{1} J_{\mathrm{CF}}=282 \mathrm{~Hz}, \mathrm{CF}_{3}\right), 156.3(\mathrm{q}$, $\left.{ }^{2} J_{\mathrm{CF}}=37 \mathrm{~Hz}, C C_{3}\right), 165.2(\mathrm{PhC}=\mathrm{O}) .{ }^{29} \mathrm{Si}\left(\mathrm{CDCl}_{3}, 300 \mathrm{~K}\right): \delta$-75.5. Anal. Calcd for $\mathrm{C}_{15} \mathrm{H}_{22} \mathrm{ClN}_{4} \mathrm{O}_{2} \mathrm{~F}_{3} \mathrm{Si}: \mathrm{C}$, 43.84; H, 5.40; N, 13.64. Found: C, 43.34; H, 5.84; N, 13.73.

[ $N$-(dimethyl) $N$-(trifluoroacethydrazido)methyl-C,O][N-

(isopropylideneimino)benzimidato- $\mathbf{N}, \mathbf{O}]$ methylsilicon chloride (7a). The first step, preparation of $\mathbf{3}$, was done as described above for $\mathbf{5 a}$, from $0.322 \mathrm{~g}$ (1.97 mmol) 2, and $0.441 \mathrm{~g}$ (1.93 mmol) 1a. To the crude 3 was added $5 \mathrm{~mL}$ of $\mathrm{CHCl}_{3}$ and $0.497 \mathrm{~g}$ (2.00 mmol) of TMShydrazide 6a. The mixture was stirred at RT for $20 \mathrm{~h}$, followed by low pressure removal of volatiles, leaving a foamy residue. Ether was added by condensation and the solution was refluxed for $10 \mathrm{~h}$, during which the product precipitated. $0.527 \mathrm{~g}$ (65\% yield) of 7a was obtained after decantation and drying. Mp 133-134.5 ${ }^{\circ} \mathrm{C} .{ }^{1} \mathrm{H}$ NMR $\left(\mathrm{CDCl}_{3}, 300 \mathrm{~K}\right): \delta 0.84$ (s, 3H, MeSi), 2.50, 2.76 (2s, 6H, CMe), 3.75, 3.79 (2s, 6H, NMe), 3.55, $4.76\left(\mathrm{ABq},{ }^{2} J=16.4 \mathrm{~Hz}, 2 \mathrm{H}, \mathrm{CH}_{2}\right)$, 7.39-7.96 (m, 5H, Ph). ${ }^{13} \mathrm{C} \mathrm{NMR}\left(\mathrm{CDCl}_{3}, 300 \mathrm{~K}\right): \delta 4.19(\mathrm{MeSi}), 23.3,26.7\left(\mathrm{C}\left(\mathrm{CH}_{3}\right)_{2}\right), 54.8$, $56.0(\mathrm{NMe}), 60.7\left(\mathrm{CH}_{2}\right), 116.3\left(\mathrm{q},{ }^{1} J_{\mathrm{CF}}=280 \mathrm{~Hz}, \mathrm{CF}_{3}\right), 127.3,128.0,128.7,133.2(\mathrm{Ph}), 157.4(\mathrm{q}$, $\left.{ }^{2} J_{\mathrm{CF}}=39 \mathrm{~Hz}, C \mathrm{CF}_{3}\right), 162.9,178.3(\mathrm{C}=\mathrm{N}) .{ }^{29} \mathrm{Si}\left(\mathrm{CDCl}_{3}, 300 \mathrm{~K}\right): \delta$-73.6. Anal. Calcd for $\mathrm{C}_{16} \mathrm{H}_{22} \mathrm{ClF}_{3} \mathrm{~N}_{4} \mathrm{O}_{2} \mathrm{Si}$ : C, 45.44; H, 5.24; N, 13.25. Found: C, 45.25; H, 5.10; N, 13.13. 
[ $N$-(dimethyl) $N$-(trifluoroacethydrazido)methyl-C,O][N-(isopropylideneimino)phenylacetimidato-N,O]methylsilicon chloride (7b). $\mathbf{7 b}$ was prepared as described for $\mathbf{7 a}$, using $0.321 \mathrm{~g}$ (1.96 mmol) of 2 and $0.436 \mathrm{~g}(1.91 \mathrm{mmol}) \mathbf{1 a}$, and $0.570 \mathrm{~g}(2.17 \mathrm{mmol})$ of $\mathbf{6 b} .0 .630 \mathrm{~g}(75 \%$ yield) of $7 \mathbf{b}$ was obtained, mp $125-127{ }^{\circ} \mathrm{C} .{ }^{1} \mathrm{H} \mathrm{NMR}\left(\mathrm{CDCl}_{3}, 300 \mathrm{~K}\right): \delta 0.77$ (s, 3H, MeSi), 2.61, 2.45 (2s, 6H, C( $\left.\left.\mathrm{CH}_{3}\right)_{2}\right), 3.44,3.67$ (2s, 6H, NMe), 3.61, $4.31\left(\mathrm{ABq},{ }^{2} J=15.9 \mathrm{~Hz}, 2 \mathrm{H}, \mathrm{CH}_{2}\right), 3.58$, $3.62\left(\mathrm{ABq},{ }^{2} J=14.7 \mathrm{~Hz}, 2 \mathrm{H}, \mathrm{PhCH}_{2}\right), 7.28(\mathrm{~m}, 5 \mathrm{H}, \mathrm{Ph}) .{ }^{13} \mathrm{C} \mathrm{NMR}\left(\mathrm{CDCl}_{3}, 300 \mathrm{~K}\right): \delta 4.2$ (MeSi), 22.6, $26.2\left(\mathrm{C}\left(\mathrm{CH}_{3}\right)_{2}\right.$, 56.1, $56.5(\mathrm{NMe}), 37.7\left(\mathrm{CH}_{2} \mathrm{Ph}\right), 59.2\left(\mathrm{CH}_{2}\right), 116.4\left(\mathrm{q},{ }^{1} J_{\mathrm{CF}}=282\right.$ $\left.\mathrm{Hz}, \mathrm{CF}_{3}\right), 127.6,128.7,128.9,133.5(\mathrm{Ph}), 157.3\left(\mathrm{q},{ }^{2} J_{\mathrm{CF}}=37 \mathrm{~Hz}, C_{C F}\right), 167.3,178.5(\mathrm{C}=\mathrm{N})$. ${ }^{29} \mathrm{Si}\left(\mathrm{CDCl}_{3}, 300 \mathrm{~K}\right): \delta$-74.9. Anal. Calcd for $\mathrm{C}_{17} \mathrm{H}_{24} \mathrm{~N}_{4} \mathrm{O}_{2} \mathrm{~F}_{3} \mathrm{ClSi}$ : C, 46.73; H, 5.54; N, 12.82. Found: C, 46.59; H, 5.63; N, 12.68.

[ $N$-(dimethyl) $N$-(trifluoroacethydrazido)methyl-C,O] [ $N($ dimethylamino)pivaloimidato$\mathbf{N}, \mathbf{O}$ ]methylsilicon chloride (8b). 8b was synthesized as described for 5a above, from $0.619 \mathrm{~g}$ (3.79 mmol) of $\mathbf{2}$ and $0.848 \mathrm{~g}$ (3.71 mmol) of 1a. The crude $\mathbf{3}$ was treated with $0.824 \mathrm{~g}$ (3.81 mmol) of 1b. $1.046 \mathrm{~g}$ (78 \% yield) of $\mathbf{8 b}$ was obtained, mp 128-129 ${ }^{\circ} \mathrm{C} .{ }^{1} \mathrm{H}$ NMR $\left(\mathrm{CDCl}_{3}, 300\right.$ $\mathrm{K}): \delta 0.65$ (s, 3H, MeSi), 1.17 (s, 9H, t-Bu), 2.61, 2.94, 3.64, 3.69 (4s, 12H, NMe), 3.10, 3.96 $\left(\mathrm{ABq},{ }^{2} J=15.7 \mathrm{~Hz}, 2 \mathrm{H}, \mathrm{CH}_{2}\right) .{ }^{13} \mathrm{C} \mathrm{NMR}\left(\mathrm{CDCl}_{3}, 300 \mathrm{~K}\right): \delta-1.6(\mathrm{MeSi}), 26.3\left(\mathrm{C}\left(\mathrm{CH}_{3}\right)_{3}\right), 35.3$ $\left(C\left(\mathrm{CH}_{3}\right)_{3}\right), 48.2$, 48.9, 52.7, $53.5(\mathrm{NMe}), 62.8\left(\mathrm{CH}_{2}\right), 116.1$ (q, $\left.{ }^{1} J_{\mathrm{CF}}=278 \mathrm{~Hz}, \mathrm{CF}_{3}\right), 157.3(\mathrm{q}$, $\left.{ }^{2} J_{\mathrm{CF}}=39 \mathrm{~Hz}, C \mathrm{CF}_{3}\right), 174.4(\mathrm{t}-\mathrm{BuC}) .{ }^{29} \mathrm{Si}\left(\mathrm{CDCl}_{3}, 300 \mathrm{~K}\right): \delta$-63.2. Anal. Calcd for $\mathrm{C}_{13} \mathrm{H}_{26} \mathrm{ClF}_{3} \mathrm{~N}_{4} \mathrm{O}_{2} \mathrm{Si}$ : C, 39.94; H, 6.70; N, 14.33. Found: C, 39.42; H, 7.09; N, 14.44.

[ $N$-(dimethyl) $N$-(trifluoroacethydrazido)methyl-C,O] [N(dimethylamino)benzimidato$\mathbf{N}, \mathbf{O}]$ methylsilicon chloride $(\mathbf{8 c})$. 8c was synthesized as described for 5a, from $0.587 \mathrm{~g}$ (3.59 mmol) of $\mathbf{2}$ and $0.809 \mathrm{~g}$ (3.55 mmol) of 1a. The crude 3 reacted with $0.899 \mathrm{~g}$ (3.80 mmol) of 1c. $1.018 \mathrm{~g}$ (75 \% yield) of 8c was obtained, mp 104-105 ${ }^{\circ} \mathrm{C} .{ }^{1} \mathrm{H} \mathrm{NMR}\left(\mathrm{CDCl}_{3}, 300 \mathrm{~K}\right): \delta 0.72$ (s, 3H, MeSi), 2.72, 3.02, 3.64, 3.70 (4s, 12H, NMe), 3.25, $5.98\left(\mathrm{ABq},{ }^{2} J=15.6 \mathrm{~Hz}, 2 \mathrm{H}, \mathrm{CH}_{2}\right)$, 7.24-7.80 (5H, Ph). ${ }^{13} \mathrm{C} \mathrm{NMR}\left(\mathrm{CDCl}_{3}, 300 \mathrm{~K}\right): \delta$-1.01 (MeSi), 48.9, 49.5, 52.9, 53.6 (NMe), $62.9\left(\mathrm{CH}_{2}\right), 116.2\left(\mathrm{q},{ }^{1} J_{\mathrm{CF}}=279 \mathrm{~Hz}, \mathrm{CF}_{3}\right), 127.6,128.1,128.6,132.8(\mathrm{Ph}), 157.5\left(\mathrm{q},{ }^{2} J_{\mathrm{CF}}=39\right.$ $\left.\mathrm{Hz}, \mathrm{CCF}_{3}\right), 163.5(\mathrm{C}=\mathrm{N}) .{ }^{29} \mathrm{Si}\left(\mathrm{CDCl}_{3}, 300 \mathrm{~K}\right): \delta-62.2$. Anal. Calcd for $\mathrm{C}_{15} \mathrm{H}_{22} \mathrm{ClF}_{3} \mathrm{~N}_{4} \mathrm{O}_{2} \mathrm{Si}$ : C, 43.85; H, 5.40; N, 13.64. Found: C, 44.89; H, 6.05; N, 13.30.

[ $N$-methyl- $N$-(trifluoroacetamidomethyl)-C,O]methyldichlorosilane (11a). 0.983 g (4.93 mmol) of $\mathbf{1 0 a}$ and $0.805 \mathrm{~g}$ (4.92 mmol) of 2 was dissolved in $5 \mathrm{~mL} \mathrm{CHCl}_{3}$ and the solution was kept at reflux temperature for 5 days. The volatiles were removed under reduced pressure, and the remaining crystalline solid was recrystallized from $10 \mathrm{~mL}$ of hexane, to give $1.079 \mathrm{~g}$ (86\% yield) of 11a, mp $67-68{ }^{\circ} \mathrm{C} .{ }^{1} \mathrm{H} \mathrm{NMR}\left(\mathrm{CDCl}_{3}, 300 \mathrm{~K}\right): \delta 0.99$ (s, 3H, SiMe), $3.20\left(\mathrm{~s}, 2 \mathrm{H}, \mathrm{CH}_{2}\right)$, 3.25 (s, 3H, NMe). ${ }^{13} \mathrm{C} \mathrm{NMR}\left(\mathrm{CDCl}_{3}, 300 \mathrm{~K}\right): \delta 8.49(\mathrm{MeSi}), 37.3(\mathrm{NMe}), 45.9\left(\mathrm{CH}_{2}\right), 116.0$ $\left(\mathrm{q},{ }^{1} J_{\mathrm{CF}}=285 \mathrm{~Hz}, \mathrm{CF}_{3}\right), 158.0\left(\mathrm{q},{ }^{2} J_{\mathrm{CF}}=39 \mathrm{~Hz}, \mathrm{CCF}_{3}\right) .{ }^{29} \mathrm{Si}\left(\mathrm{CDCl}_{3}\right): \delta 0.47(300 \mathrm{~K}), 4.48(330$ $\mathrm{K})$, -5.08 (270 K). Anal. Calcd for $\mathrm{C}_{5} \mathrm{H}_{8} \mathrm{Cl}_{2} \mathrm{~F}_{3} \mathrm{NOSi}$ : C, 23.63; H, 3.17; N, 5.51. Found: C, 23.86; $\mathrm{H}, 3.26$; N, 5.63.

[ $N$-methyl- $N$-(trifluoroacetamidomethyl)-C,O][N-(dimethylamino)trifluoroacetimidatoN,O]methylchlorosilicon (12). $1.019 \mathrm{~g}$ (4.01 mmol) of $\mathbf{1 1 a}$ and $0.896 \mathrm{~g}$ (4.92 mmol) of 1a were dissolved in $5 \mathrm{~mL} \mathrm{CHCl}_{3}$. The mixture was stirred at RT for $1 \mathrm{~h}$. The volatiles were removed 
under reduced pressure, and the remaining product was washed by $10 \mathrm{~mL}$ of hexane, to give a viscous residue $1.498 \mathrm{~g}$ (99\% yield). ${ }^{1} \mathrm{H}$ NMR $\left(\mathrm{CDCl}_{3}, 300 \mathrm{~K}\right): \delta 0.54$ (s, 3H, SiMe), 2.86 (s, 6H, $\mathrm{NNMe}_{2}$ ), 3.31 (s, 3H, CNMe). ${ }^{13} \mathrm{C}$ NMR (toluene-d $\left.8,300 \mathrm{~K}\right): \delta 11.2$ (MeSi), 37.3 (NNMe), 49.6 $\left(\mathrm{CNMe}_{2}\right), 50.5\left(\mathrm{CH}_{2}\right), 116.0$ (q, $\left.{ }^{1} J_{\mathrm{CF}}=288 \mathrm{~Hz}, \mathrm{CF}_{3}\right), 118.8$ (q, $\left.{ }^{1} J_{\mathrm{CF}}=285 \mathrm{~Hz}, \mathrm{CF}_{3}\right), 151.0$ (q, $\left.{ }^{2} J_{\mathrm{CF}}=39 \mathrm{~Hz}, \mathrm{NNCCF}_{3}\right), 158.0\left(\mathrm{q},{ }^{2} J_{\mathrm{CF}}=39 \mathrm{~Hz}, \mathrm{NCO}\right) .{ }^{29} \mathrm{Si}$ (toluene-d 8 ): $\delta-79.6(300 \mathrm{~K}) ;-51.1$ (360 K); -116.5 (170 K).

\section{[ $N$-methyl- $N$-(acetamidomethyl)-C,O][ $N, N^{\prime}$ (dimethyl)benzhydrazido-N,O]-methylsilicon}

tetraphenylborate (16). 16 was prepared via crude 11b without isolation of the intermediate. $0.665 \mathrm{~g}$ (4.58 mmol) of $\mathbf{1 0 b}$ and $0.750 \mathrm{~g}$ (4.59 mmol) of 2 were dissolved in $10 \mathrm{~mL} \mathrm{CHCl}_{3}$ and the solution was kept at room temperature for 15 days. The volatiles were removed under reduced pressure, and to the remaining crude solid $\mathbf{1 1 b}$ was added $10 \mathrm{~mL}$ of hexane and $1.101 \mathrm{~g}$ (4.66 mmol) 4c. ${ }^{15}$ The mixture was kept for $24 \mathrm{~h}$ at room temperature, followed by removal of volatiles under reduced pressure $(1 \mathrm{mmHg})$. The remaining oil was treated with $2.5 \mathrm{~mL}$ of $\mathrm{CHCl}_{3}$ and $0.792 \mathrm{~g}$ ( $5.17 \mathrm{mmol})$ of $\mathrm{Me}_{3} \mathrm{SiBr}$, and warmed up to reflux temperature for $1 \mathrm{~h}$ followed by $24 \mathrm{~h}$ at room temperature. The volatiles were removed under reduced pressure, and to the foamy residue were added $15 \mathrm{~mL}$ of $\mathrm{CH}_{3} \mathrm{CN}$ and $1.957 \mathrm{~g}$ (5.72 mmol) of $\mathrm{NaBPh}_{4}$ and the mixture was allowed to stir for 3h. After evaporation the foamy mass was crystallized from $\mathrm{Et}_{2} \mathrm{O}$, and a single crystal was grown from $\mathrm{THF} / \mathrm{CHCl}_{3}$ for crystallographic analysis. Mp $107-110{ }^{\circ} \mathrm{C}$. ${ }^{1} \mathrm{H} \mathrm{NMR}$ $\left(\mathrm{CDCl}_{3}, 300 \mathrm{~K}\right): \delta 0.38$ (s, 3H, MeSi), 1.75, 2.31, 2.82, 2.93 (4s, 12H, NMe), 2.21, 2.33 (ABq, ${ }^{2} J$ $\left.=16.9 \mathrm{~Hz}, 2 \mathrm{H}, \mathrm{CH}_{2}\right), 6.70-7.60(\mathrm{~m}, 25 \mathrm{H}, \mathrm{Ph}) .{ }^{13} \mathrm{C} \mathrm{NMR}\left(\mathrm{CDCl}_{3}, 300 \mathrm{~K}\right): \delta 1.8(\mathrm{MeSi}), 16.2$ $\left(\mathrm{OCCH}_{3}\right)$, 32.3, 36.2, 36.9, (NMe), $39.4\left(\mathrm{CH}_{2}\right), 124.1,127.8,128.0,131.9(\mathrm{Ph}), 170.3,173.8$ $(\mathrm{C}=\mathrm{O}) .{ }^{29} \mathrm{Si}\left(\mathrm{CDCl}_{3}, 300 \mathrm{~K}\right): \delta$-59.1. Anal. Calcd for $\mathrm{C}_{38} \mathrm{H}_{42} \mathrm{~N}_{3} \mathrm{O}_{2} \mathrm{BSi}$ : C, 74.62; H, 6.92; N, 6.87. Found: C, 74.44; H, 7.05; N, 6.69.

\section{Acknowledgments}

Financial support from the Israel Science Foundation, grant No. ISF-139/05, and from INTAS, project 03-51-4164, is gratefully acknowledged.

* Corresponding author

$†$ Deceased July 4, 2004

\section{References and Notes}

1. (a) Tandura, S. N.; Voronkov, M. G.; Alekseev, N. V. Top. Curr. Chem. 1986,131, 99.

(b) Kost, D.; Kalikhman, I. In The Chemistry of Organic Silicon Compounds; Rappoport, Z.; Apeloig, Y. Eds.; Wiley: Chichester, U.K, 1998; Vol. 2, Part 2, pp 1339 - 1445. (c) Lukevics, E.; Pudova, O. A.; Chem. Heterocycl. Compd. (Engl. Transl. 
1996, 32, 1381. (d) Holmes, R. R. Chem. Rev. 1996, 96, 927. (e) Chuit, C.; Corriu, R. J. P.; Reyé, C. In The Chemistry of Hypervalent Compounds, Kin-ya Akiba, Ed.; Wiley-VCH: Weinheim, Germany 1999, pp 81 - 146. (f) Kira, M.; Zhang, L. C. In The Chemistry of Hypervalent Compounds, Kin-ya Akiba, Ed.; Wiley-VCH: Weinheim, Germany, 1999, pp 147 - 169. (g) Brook, M. A. Silicon in Organic, Organometallic and Polymer Chemistry, Wiley: New York 2000, pp 97 - 115. (h) Tacke, R.; Seiler, O. In Silicon Chemistry: From the Atom to Extended Systems; Jutzi, P., Schubert, U., Eds.; Wiley-VCH: Weinheim, Germany, 2003, pp. 324 - 337. (i) Bassindale, A. R.; Glin, S. J.; Taylor, P. G. In The Chemistry of Organic Silicon Compounds; Rappoport, Z.; Apeloig, Y. Eds.; Wiley: Chichester, U.K, 1998; Vol. 2, Part 1, pp 495 - 511. (j) Verkade, J. G. Coord. Chem. Rev. 1994, 137, 233 - 295.

2. Kost, D.; Kalikhman, I. Adv. Organomet. Chem., 2004, 50, 1.

3. (a) Gostevskii, B.; Pestunovich, V.; Kalikhman, I.; Sivaramakrishna, A.; Kocher, N.; Deuerlein, S.; Leusser, D.; Stalke, D.; Kost, D. Organometallics, 2004, 23, 4346. (b) Kost, D.; Gostevskii, B.; Kocher, N.; Stalke, D.; Kalikhman, I. Angew. Chem. Int. Ed. 2003, 42, 1023.

4. (a) Kost, D.; Kalikhman, I.; Raban, M. J. Am. Chem. Soc. 1995, 117, 11512. (b) Kalikhman, I.; Krivonos, S.; Stalke, D.; Kottke, T.; Kost, D. Organometallics, 1997, 16, 3255. (c) Kost, D.; Kalikhman, I.; Krivonos, S.; Stalke, D.; Kottke, T. J. Am. Chem. Soc. 1998, 120, 4209.

5. Kost, D.; Kingston, V.; Gostevskii, B.; Ellern, A.; Stalke, D.; Walfort, B.; Kalikhman, I. Organometallics, 2002, 21, 2293.

6. (a) Gostevskii, B.; Silbert, G.; Adear, K.; Sivaramakrishna, A.; Stalke, D.; Deuerlein, S.; Kocher, N.; Voronkov, M. G.; Kalikhman, I.; Kost, D. Organometallics 2005, 24, 2913. (2) Gostevskii, B.; Adear, K.; Sivaramakrishna, A.; Silbert, G.; Stalke, D.; Kocher, N.; Kalikhman, I.; Kost, D. Chem. Comm. 2004, 1644.

7. Kalikhman, I.; Girshberg, O.; Lameyer, L.; Stalke, D.; Kost, D. J. Am. Chem. Soc. 2001, 123, 4709.

8. (a) Hillyard, R. W.; Ryan, C. M.; Yoder, C. H. J. Organomet. Chem., 1978, 153, 369. (b) Yoder, C. H.; Ryan, C. M.; Martin, G. F.; Ho, P. S. J. Organomet. Chem., 1980, 190, 1. (c) Voronkov, M. G.; Pestunovich, V. A.; Baukov, Yu. I. Organomet. Chem. USSR, 1991, 4, 593 (translated from Metalloorg. Khim. 1991, 4, 1210).

9. Kalikhman, I.; Girshberg, O.; Lameyer, L.; Stalke, D.; Kost, D. Organometallics 2000, 19, 1927.

10. (a) Kalikhman, I. D. ; Pestunovich, V. A.; Gostevskii, B. A.; Bannikova, O. B.; Voronkov, M. G. J. Organomet. Chem. 1988, 338, 169. (b) Kalikhman, I. D.; Bannikova, O. B.; Petuchov, L. P.; Pestunovich, V. A.; Voronkov, M. G. Dokl. Akad. Nauk SSSR 1986, 287, 870.

11. McKillip, W. J.; Sedor, E. A.; Culbertson, B. M.; Wawzonek, S. Chem. Rev. 1973, 73, 255. 
12. Berry, R. S. J. Chem. Phys. 1960, 32, 933.

13. For reports of two exchange barriers in pentacoordinate silicon compounds see: (a) Corriu, R. J. P.; Kpoton, A.; Poirier, M.; Royo, G.; Corey, J. Y. J. Organomet. Chem. 1984, 277, C25. (b) Kalikhman, I.; Krivonos, S.; Ellern, A.; Kost, D. Organometallics 1996, 24, 5073.

14. (a) Berlekamp, U.-H.; Jutzi, P.; Mix, A.; Neumann, B.; Stammler, H.-G.; Schoeller, W. W. Angew. Chem. Int. Ed. 1999, 38, 2048. (b) Kramarova, E. P.; Pogozhikh, S. A.; Shipov, A. G.; Negrebetsky, Vad. V.; Tandura, S. N.; Shumsky, A. N.; Artamkin, S. A.; Bylikin, S. Yu.; Ovchinnikov, Yu. E.; Baukov, Yu. I. Russ. Chem. Bull. 2001, 50, 331. (c) Kramarova, E. P.; Korlyukov, A. A.; Bylikin, S. Yu.; Shipov, A. G.; Baukov, Yu. I.; Kost, D. Russ. Chem. Bull., 2004, 53, 1135.

15. Kalikhman, I.; Krivonos, S.; Lameyer, L.; Stalke, D.; Kost, D. Organometallics 2001, 20, 1053. 